Article

\title{
The Many Faces of Graphene as Protection Barrier. Performance under Microbial Corrosion and Ni Allergy Conditions
}

\author{
Carolina Parra ${ }^{1, *}$ (D), Francisco Montero-Silva ${ }^{1}$ (D), Dana Gentil ${ }^{1}$, Valeria del Campo ${ }^{2}$, \\ Thiago Henrique Rodrigues da Cunha ${ }^{3}$, Ricardo Henríquez ${ }^{2}$, Patricio Häberle ${ }^{2}$ (1), \\ Carolina Garín ${ }^{4}$, Cristian Ramírez ${ }^{5}$, Raúl Fuentes ${ }^{6}$ (D), Marcos Flores ${ }^{7}$ and Michael Seeger 8 \\ 1 Laboratorio de Nanobiomateriales, Departamento de Física, Universidad Técnica Federico Santa María, \\ Valparaíso 2390123, Chile; monteroster@gmail.com (F.M.-S.); danagentil5@gmail.com (D.G.) \\ 2 Departamento de Física, Universidad Técnica Federico Santa María, Valparaíso 2390123, Chile; \\ valeria.delcampo@usm.cl (V.d.C.); ricardo.henriquez@usm.cl (R.H.); patricio.haberle@usm.cl (P.H.) \\ 3 Departamento de Física, CTNanotubos, Universidade Federal de Minas Gerais, Belo Horizonte 31310260, \\ Brazil; thyagoh@yahoo.com.br \\ 4 Instituto de Química, Pontificia Universidad Católica de Valparaíso, Valparaíso 3100000, Chile; \\ carolina.garin@pucv.cl \\ 5 Departamento de Ingeniería Química y Ambiental, Universidad Técnica Federico Santa María, Valparaíso \\ 2390123, Chile; cristian.ramirez@usm.cl \\ 6 Departamento de Industrias, Universidad Técnica Federico Santa María, Valparaíso 2390123, Chile; \\ raul.fuentes@usm.cl \\ 7 Laboratorio de Superficies y Nanomateriales, Departamento de Física, Facultad de Ciencias Físicas y \\ Matemáticas, Universidad de Chile, Santiago 8370448, Chile; mflorescarra@ing.uchile.cl \\ 8 Departamento de Química, Universidad Técnica Federico Santa María, Valparaíso 2390123, Chile; \\ michael.seeger@usm.cl \\ * Correspondence: carolina.parra@usm.cl; Tel.: +56-32-265-4722
}

Received: 27 October 2017; Accepted: 5 December 2017; Published: 8 December 2017

\begin{abstract}
In this work we present a study on the performance of CVD (chemical vapor deposition) graphene coatings grown and transferred on $\mathrm{Ni}$ as protection barriers under two scenarios that lead to unwanted metal ion release, microbial corrosion and allergy test conditions. These phenomena have a strong impact in different fields considering nickel (or its alloys) is one of the most widely used metals in industrial and consumer products. Microbial corrosion costs represent fractions of national gross product in different developed countries, whereas $\mathrm{Ni}$ allergy is one of the most prevalent allergic conditions in the western world, affecting around $10 \%$ of the population. We found that grown graphene coatings act as a protective membrane in biological environments that decreases microbial corrosion of $\mathrm{Ni}$ and reduces release of $\mathrm{Ni}^{2+}$ ions (source of $\mathrm{Ni}$ allergic contact hypersensitivity) when in contact with sweat. This performance seems not to be connected to the strong orbital hybridization that $\mathrm{Ni}$ and graphene interface present, indicating electron transfer might not be playing a main role in the robust response of this nanostructured system. The observed protection from biological environment can be understood in terms of graphene impermeability to transfer $\mathrm{Ni}^{2+}$ ions, which is enhanced for few layers of graphene grown on $\mathrm{Ni}$. We expect our work will provide a new route for application of graphene as a protection coating for metals in biological environments, where current strategies have shown short-term efficiency and have raised health concerns.
\end{abstract}

Keywords: microbial corrosion; CVD; graphene; nickel; sweat 


\section{Introduction}

When metals are in contact with biofilms, which naturally form under the exposure of materials to ambient moisture, miscellaneous metabolic activities lead to the production of organic and inorganic acids, volatile compounds and other chemical reactions with the metals. These processes induce a highly accelerated deterioration of the substrate known as microbiologically influenced corrosion or microbial corrosion [1]. This phenomenon represents an enormous burden to maintenance cost in metal-based infrastructure $[2,3]$.

Current strategies to prevent microbial corrosion in metallic structures aim to attack biofilms that cause microbial corrosion. They mainly include physical methods (e.g., flushing) and chemical methods (e.g., biocides) [2,4]. The use of protective epoxy coatings in order to isolate metals from environment and the application of passivation layers (e.g., thiol-based mono-layers) have been considered also as standard mitigation strategies [4]. However, compared to the lifetime of the objects being protected, all these control approaches exhibit a short-term efficiency, deteriorating and roughening as they age [5]. In addition, biocides and organic solvents present in protective layers have a negative impact in complete ecosystems where biofilms are treated [4]. With the pressure of stringent environmental regulations monotonically increasing, there is an urgent need for new environmentally friendly and sustainable microbial corrosion control strategies.

On the other hand, there is a phenomenon that, similar to microbial corrosion, includes metal ion release when a metallic material is in contact with other living systems, such as the one provided by human skin. Among metallic materials, Ni and its alloys are one of the most widely used in diverse domestic objects that come in contact with human skin. Ni has been chosen for most of these applications due to its mechanical properties, corrosion resistance, durability, appearance and availability. However, remarkable as these properties are, they do not seem to withstand direct interaction with human skin conditions. Release of $\mathrm{Ni}^{2+}$ ions from $\mathrm{Ni}$ metallic objects that come in direct contact with human skin has been related to a phenomenon known as the allergic contact hypersensitivity response to $\mathrm{Ni}[6,7]$. This is one of the most frequent contact allergies produced by manmade products [7-14] and a major source of this Ni hypersensitivity.

$\mathrm{Ni}^{2+}$ is not only released from coins [15] but also from components of earrings, watches, buttons and dental and orthopedic implants, thus increasing the incidence of $\mathrm{Ni}^{2+}$-induced contact dermatitis [16-18]. Although $\mathrm{Ni}^{2+}$ ions have been reported to trigger an innate immune response in resident skin cells [19] they are not regarded as antigenic by themselves. The process seems to be a bit more complex: when ions attach to large proteins in the epidermis, our organism attempts to get rid of the nickel-protein complexes thus causing the emergence of the immune response, such as an inflammatory reaction on the skin [14]. When nickel-containing materials are in contact with the skin, metallic nickel can be solubilized by sweat, which is followed by the dermal absorption and skin penetration that leads to an enhanced allergic reaction to nickel [20]. This accelerated dissolution, promoted by immersion in sweat, is in fact the experimental condition used to test biocompatibility of Ni-containing materials, according to international regulations [21,22]. Reduction of nickel penetration through skin has been addressed by different topical agents $[23,24]$, which in only a few cases have proven to be safe and effective $[25,26]$. Even rubber gloves are inefficient in preventing the contact with nickel, as metal ions penetrate through them [27].

Different nanoscale approaches have been used to produce certain degrees of control over contact allergy and microbial corrosion issues. For instance, the application of calcium phosphate and calcium carbonate nanoparticles to the skin seems to be effective in preventing the allergy towards $\mathrm{Ni}^{2+}$, by capturing nickel ions [28], which are subsequently removed from the skin. Although such approach seems to be effective, it raises concerns about the risks of absorption of nanoparticles through the skin [29,30]. Similarly, metal nanoparticle-based coatings have been also used for microbial corrosion control [31,32]. However, these coatings fall into the biocide category, exhibiting a strong bactericide effect coming from the release of metallic ions from the nanoparticles. 
Recently our group and others have reported $\mathrm{Cu}$ microbial corrosion passivation using single-layer CVD graphene (SLG) grown on that metal $[5,33,34]$. Although SLG effectively protects copper, coupling between graphene and copper electronic states is very weak compared to electronic interfacial bonding in other graphene-metal systems, such as graphene on $\mathrm{Ni}$ or graphene on $\mathrm{Ti} / \mathrm{Au}$ [35-37]. Electronic coupling becomes especially relevant when biological response of CVD graphene-coated metals is considered, due to the reported connection between electron transfer from these material systems to microorganisms and cell death [38]. When protection of metals (other than $\mathrm{Cu}$ ) from biological interaction using graphene coatings is pursued, a different and interesting scenario is found. It is important to highlight that microbial corrosion cannot be completely linked to a single chemical reaction because it is influenced by the complex processes of microorganisms performing different electrochemical reactions and secreting proteins and metabolites that have effects over a material's damage. Although corrosion-resisting properties of graphene coatings have been widely studied $[39,40]$, evaluation of graphene performance under microbiologically-assisted corrosion conditions presents a different scenario, especially considering that graphene/metal system performance depends on graphene and underlying metal electronic interaction. From the biological point of view, graphene grown on $\mathrm{Ni}, \mathrm{Cu}$ or any other metal or alloy behaves differently. In the case of $\mathrm{Ni}$, for instance, graphene's electronic structure is disturbed through a strong hybridization of the metal's d-orbital and $\pi$ graphene's orbital forming a chemisorption interface [37]. In this scenario the strong coupling between $\mathrm{Ni}$ and graphene electronic states might play a major role in the biological response of the nanoscale-modified materials that needs to be addressed.

Motivated by the need of studies exploring the protection that graphene coatings offer to other relevant metals (other than copper), we present a study on the efficiency of graphene grown and transferred on $\mathrm{Ni}$ as an ionic barrier under two biological conditions, microbial corrosion and sweat immersion. Chemical vapor deposition (CVD) graphene, with surface areas in the centimeter square range, has been chosen as coating due to its versatility and lack of intrinsic cytotoxicity [41]. This condition is opposite to its close relative, graphene oxide (GO), formed by micro- or nanosized flakes of functionalized graphene in powder or solution, which has been shown to present an antibacterial activity [42].

In this work we explored the efficiency of as-grown few layer graphene (FLG) and transferred graphene onto Ni foils. We mainly focus on the way in which these nanostructured coatings modify interaction between: (1) Ni and bacteria (to test microbial corrosion passivation of such coatings) and (2) $\mathrm{Ni}$ and sweat (to evaluate $\mathrm{Ni}$ ion release from coated samples in conditions given by international test to quantify material biocompatibility).

\section{Materials and Methods}

Graphene grown on Ni and graphene transferred onto Ni surfaces were included in this study to establish a comparison between performances of these graphene coatings obtained through different methodologies. The performance of graphene transferred on Ni will allow a comparison between the same type of nanometric membrane but with different electronic interaction (hybridization) with metallic substrate; weak coupling for graphene transferred on $\mathrm{Ni}$ and strong for grown samples [35,36]. Graphene growth (for transferred samples) is performed through chemical vapor deposition (CVD) with methane as precursor using $25 \mu \mathrm{m}$ thick copper foil (99.99\% purity) as synthesis substrate. The CVD growth process was performed at $1000^{\circ} \mathrm{C}$ under a methane-hydrogen flow rate of $20 \mathrm{sccm}$ and $10 \mathrm{sccm}$ respectively, as reported in Ref. [43,44]. Base pressure prior to carbon precursor gas entry to the furnace was $8.6 \times 10^{-5} \mathrm{hPa}$ whereas during graphene growth was kept at $1.2 \times 10^{-2} \mathrm{hPa}$. A slight modification of this methodology is introduced by supplying this mixed flux in five steps of 20 min each. Between each step, the sample was held only under the hydrogen flux for $10 \mathrm{~min}$ to ensure a high coverage. The final methane step was followed by rapid cooling under a hydrogen-argon flux of $10 \mathrm{sccm}$ and $20 \mathrm{sccm}$ respectively. Similarly, few-layer graphene grown on nickel was obtained 
through methodology reported in ref. [45], using a $30 \mu \mathrm{m}$ Ni foil substrate. Average coating thickness was 4-monolayer thickness according to Raman (see sample characterization section).

Single-layer graphene was transferred onto Ni substrate using the PMMA-assisted method [33]. For this, a layer of poly (methyl methacrylate) (PMMA) is spin-coated on the initial graphene grown on copper sample. Detachment of the PMMA/graphene layer is done by copper etching using $2.28 \mathrm{wt} \%$ ammonium persulfate aqueous solution. Graphene/PMMA layer is washed with deionized water, manually transferred onto the nickel surface and baked to improve graphene substrate adhesion. Finally, the PMMA layer is dissolved with acetone. The obtained graphene-coated Ni sample was used as substrate for a second, third and fourth transfer process, leading to four layers graphene transferred onto Ni (4MLG). The presence of PMMA residues is a drawback of this low-cost method and it is a critical aspect especially for electronic applications where PMMA scattering centers decrease carrier mobility [46]. For biological applications, such as those reported here, presence of PMMA residues does not affect either biocompatibility of the system [47] or bacterial adhesion to surface [41].

Corresponding Ni control substrates were prepared treating fresh $\mathrm{Ni}(\mathrm{NiF})$ foils $(99.8 \%$, Alfa Aesar, Tewksbury, MA, USA, $20 \mu \mathrm{m}$ thickness) under the same temperature and hydrogen pressure conditions used for graphene growth but without the carbon precursor gas. Thermally treated Ni samples (control samples) will be called NiT. Samples of $1 \mathrm{~cm}^{2}$ surface area were used for all measurements.

A combination of scanning electron microscopy (SEM) (EVO MA-10, Carl Zeiss, Oberkochen, Germany), scanning tunneling microscopy (STM, UHV-VT, Omicron GmbH, Uppsala, Sweden) and X-ray photoelectron spectrometry (XPS; PerkinElmer PHI 1257, Perkin Elmer, Waltham, MA, USA, $\mathrm{Al} \mathrm{K} \alpha$ source, $1486.6 \mathrm{eV}$ ) was used to characterize samples morphology and chemical environment. Prior to STM and XPS analysis, where ultra-high vacuum conditions are required $\left(1 \times 10^{-10}\right.$ torr), samples were annealed at $100{ }^{\circ} \mathrm{C}$ for $20 \mathrm{~min}$ to remove all gases adsorbed on sample surface. Graphitic quality of as-grown FLG was investigated by MicroRaman measurements (inVia, Renishaw, Gloucestershire, UK, $532 \mathrm{~nm}$ laser) at ambient conditions at low laser power $(<1 \mathrm{~mW})$.

Surface hydrophobicity of coated and uncoated Ni samples was determined by contact angle measurements. For this characterization a drop of milliQ water $(2 \mu \mathrm{L})$ was placed on the surface of coated and uncoated samples and images were immediately captured using a high-resolution camera. Bacterial hydrophobicity was measured following standard methods [48] with some modifications. A bacterial strain suspended in $40 \mathrm{~mL}$ of water, $0.5 \% \mathrm{NaCl}$ and $2 \% \mathrm{NaCl}$ were filtered on a micropore cellulose nitrate filter (pore size $0.45 \mu \mathrm{m}$, Sartorius ${ }^{\mathrm{TM}}$ 1140647ACN, Sartorius Stedim Biotech, Goettingen, Germany) by filtration of the suspension using negative pressure. The filters with a bacteria film were dried at room temperature during $90 \mathrm{~min}$ in order to obtain a stable water contact angle measured by sessile drop method using $1 \mu \mathrm{L}$ of distilled. The contact angle was measured based on image analysis [49] using the image processing software Image J (bundled with 64-bit Java 1.6.0_24, public domain) with the plug-in Drop Shape Analysis based on B-spline snakes algorithm developed by ref. [50].

To explore response of graphene coatings (FLG and 4MLG) to biological environments and their ability to prevent microbial corrosion of Ni, we used Escherichia coli MG1655 cultures, which have been reported to cause metal microbial corrosion [51,52]. Bacterial cultures were grown until prestationary growth phase in a low ionic strength medium that contained meat extract $\left(5 \mathrm{~g} \cdot \mathrm{L}^{-1}\right)$ and yeast extract $\left(5 \mathrm{~g} \cdot \mathrm{L}^{-1}\right)$. The bacterial cultures were concentrated by centrifugation $(5000 \times \mathrm{g}, 5 \mathrm{~min})$, washed three times with Milli-Q water, and finally resuspended up to a turbidity of 3.0 at $600 \mathrm{~nm}$. The turbidity of this stock dispersion is equivalent to a bacterial concentration of $\sim 1 \times 10^{9} \mathrm{CFU} / \mathrm{mL}^{-1}$ (Colony forming units per milliliter). This high bacterial concentration was chosen to ensure response of graphene coatings is robust enough, even for large number of bacteria. Milli-Q water was used as dispersant to avoid bacterial duplication and the forthcoming accumulation of mineral crystals that may interfere with the collection of microscopy images or cause unwanted chemical reactions with the samples. Nickel release from metallic samples exposed to bacteria was determined by Inductively Coupled Plasma (ICP) (Perkin Elmer Nexion 350D, Perkin Elmer, Waltham, MA, USA). Control samples (NiT) 
were exposed to Milli-Q water without bacteria. After $24 \mathrm{~h}$, bacteria were recovered, poured into $2.5 \mathrm{~mL}$ of $15 \mu \mathrm{M}$ EDTA (ethylenediaminetetraacetic acid) (Sigma Aldrich, Darmstadt, Germany) solution $(\mathrm{pH} 10)$ and centrifuged at $5000 \times \mathrm{g}$ during $10 \mathrm{~min}$. The supernatant was recovered, and the total $\mathrm{Ni}$ concentration was also quantified by ICP.

Cell viability (inverse to cell death) was monitored to evaluate the antibacterial activity of coated and uncoated Ni samples. Such antibacterial performance is a direct consequence of Ni ions release and, in our case, will be an indirect indicator of Ni microbial corrosion (in addition to previously mentioned ICP measurements). One volume (100 $\mu \mathrm{L})$ of E. coli MG1655 stock dispersion was placed on each sample surface in order to obtain a final bacterial density of $60 \mu \mathrm{L} / \mathrm{cm}^{2}$. Sample + bacteria systems were incubated at $37^{\circ} \mathrm{C}$ during $24 \mathrm{~h}$ in a humidity chamber to avoid evaporation. Once this incubation period completed, bacteria were recovered with 3 volumes of Milli-Q water using a standard micropipette. Cell viability at 0 and $24 \mathrm{~h}$ was determined using the microdot methodology [51]. Each experimental trial was conducted in triplicate. For SEM characterization, bacteria were fixed on samples with $3 \%(v / v)$ glutaraldehyde and dehydrated by washing with a graded ethanol series (from $10 \%$ to $100 \%$ ), followed by critical-point drying and gold coating.

To study the response of graphene-coated $\mathrm{Ni}$ samples to sweat exposure immersion tests were performed for FLG, 4MLG and Ni samples. The artificial sweat solution was prepared similar to EN1811 [51], using $0.5 \mathrm{wt} \%$ sodium chloride, $0.1 \mathrm{wt} \%$ lactic acid, $0.1 \mathrm{wt} \%$ urea and normal ultrapure water (not aerated as described in the standard) [53,54]. The $\mathrm{pH}$ of the solution was adjusted to $\mathrm{pH} 6.5$ using $1 \mathrm{wt} \%$ ammonia solution. Samples were exposed to artificial sweat for one week and then solution were recovered for ICP Ni ion concentration quantification.

\section{Results and Discussion}

Morphological characterization of samples prior to bacterial and sweat contact was obtained by SEM (Figure 1a-d). Fresh Ni samples (NiF) showed well-defined stripes across their surfaces (Figure 1a). In contrast, thermally treated Ni foils (Figure 1b) exhibited a smooth surface covered with deep grain boundaries and less pronounced stripe marks. Scanning electron micrographs of FLG grown on Ni showed graphene smooth areas bounded by wrinkles on top of nickel substrate (Figure 1c). Four layers of graphene transferred into Ni (4MLG) shows typical wrinkles produced during PMMA assisted transfer method (Figure 1d). This implies thickness spatial inhomogeneity of graphene coating across the sample surface, leading to thicker graphene regions where wrinkles are located. Reproducibility of transferred graphene coatings is lower than the obtained for grown graphene coatings, but in this case provide relevant information regarding a graphitic system where electronic coupling with metallic substrate is reduced.

Scanning tunneling microscopy in ultrahigh vacuum conditions was used to visualize FLG grown on $\mathrm{Ni}$ with nanoscale and atomic resolution (Figure 1e). Characteristic fingerprints of high-quality graphitic materials $[55,56]$ were observed through atomic-resolved topographies. Zoom-in on a Ni terrace shows a triangular structure with $2.4 \AA$ lattice distance (according to Fourier transform analysis).

To verify the graphitic quality of SLG, transferred graphene (4MLG) and FLG coatings, we performed microRaman measurements on these samples. Multiple areas of these samples were analyzed, and representative spectra are shown in Figure $1 \mathrm{f}-\mathrm{h}$. Single-layer graphene grown on $\mathrm{Cu}$ (Figure 1f) presents sharp G $\left(1584 \mathrm{~cm}^{-1}\right)$ and $2 \mathrm{D}\left(\sim 2688 \mathrm{~cm}^{-1}\right)$ bands, with a small G/2D $(\sim 0.23)$, consistent with literature [35]. Upshifting of 2D band with increasing the number of SLG transferred on Ni is observed for 4MLG (2D band at $2698 \mathrm{~cm}^{-1}$ ). Raman spectra displayed typically sharp G $\left(1584 \mathrm{~cm}^{-1}\right)$ and broad 2D ( 2701 $\left.\mathrm{cm}^{-1}\right)$ bands for FLG (Figure 1h), consistently with 4-5 layers of graphene, according to values reported in literature [56-58]. 
(a)

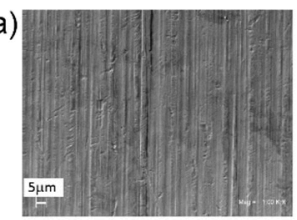

(c)

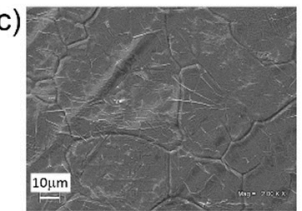

(e)

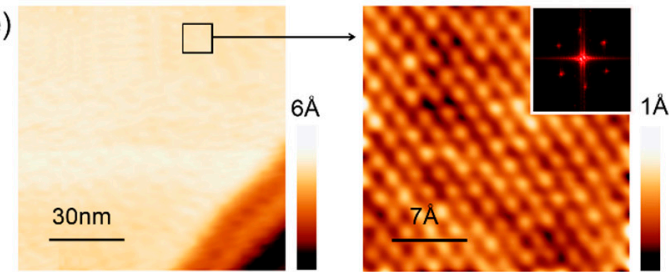

(b)

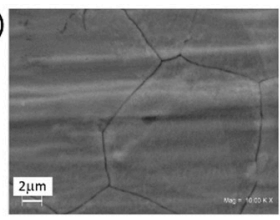

(d)

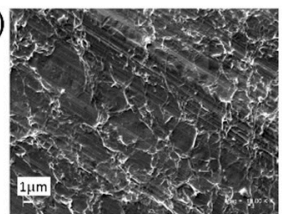

$1 \AA$

$\AA$

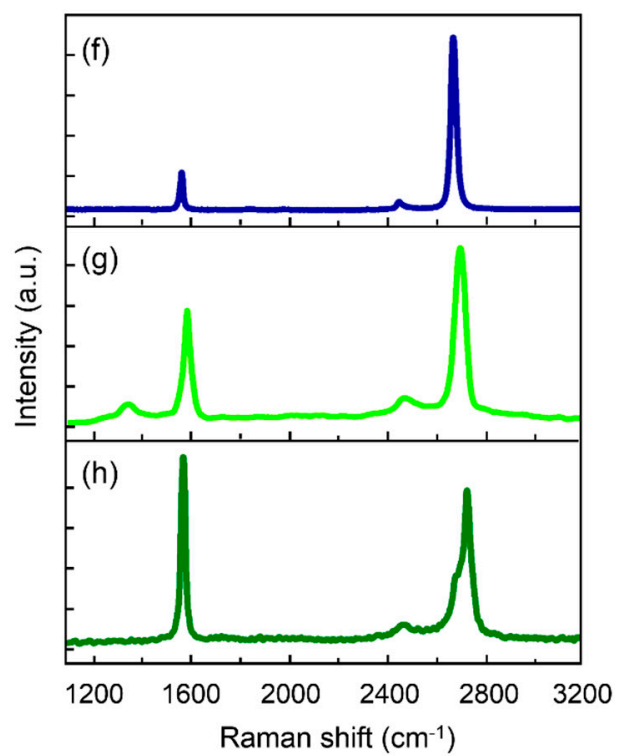

Figure 1. Structural and morphological characterization of samples. SEM images of (a) NiF; (b) NiT; (c) FLG on Ni; (d) 4MLG on Ni; (e) Large-scale STM topography $\left(100 \times 100 \mathrm{~nm}^{2}\right)$ of few-layers graphene grown on $\mathrm{Ni}\left(\mathrm{I}=0.7 \mathrm{nA}, \mathrm{V}_{\mathrm{BIAS}}=0.1 \mathrm{~V}\right)$. High-magnification STM image $\left(2.5 \times 2.5 \mathrm{~nm}^{2}\right)$ showing the triangular lattice atomic structure of few-layer graphene on $\mathrm{Ni}$ with lattice constant $2.4 \AA$, according to Fourier transform analysis (inset). Representative Raman spectra of SLG grown on Cu (for reference) (f), 4MLG tranferred on Ni (g) and FLG grown on Ni (h). Background caused by the luminescence of the copper was subtracted in the case of SLG grown and transferred on $\mathrm{Cu}$.

Surface composition information of Ni samples was obtained by means of XPS analysis (Figure 2a). In particular, we focused on the $\mathrm{Ni} 2 \mathrm{p}_{3 / 2}$ spectrum, which contains information on metallic $\mathrm{Ni}$ (peaks in red, orange and yellow), $\mathrm{NiO}$ (peak in green), and $\mathrm{Ni}(\mathrm{OH})_{2}$ (peak in blue) surface contents that are present when nickel is exposed to ambient conditions $[59,60]$. Stronger XPS metallic Ni peaks for FLG, $\mathrm{NiT}$ and $\mathrm{NiF}$ (in red) were found at $853.1 \mathrm{eV}, 856.8 \mathrm{eV}$, and $859.1 \mathrm{eV}$, respectively. These measurements reveal that although $\mathrm{Ni}(\mathrm{OH})_{2}$ signals (in blue) are present for $\mathrm{NiF}$ and $\mathrm{NiT}$ samples (and to lesser extent for FLG), they are stronger for NiF. This is in agreement with previous reports where an initial $\mathrm{Ni}$ oxide growth in metallic $\mathrm{Ni}$ saturates at few layers after which oxygen in air leads to formation of $\mathrm{Ni}(\mathrm{OH})_{2}$ on the surface, that continue growing for longer exposure to atmospheric gas pressure [60]. Similar reports have shown the formation of ultrathin $\mathrm{NiO}$ coating when graphene is grown on $\mathrm{Ni}$ foams under low-pressure CVD conditions [61]. The resulting structure was a dual oxide configuration with $\mathrm{Ni}(\mathrm{OH})_{2}$ at the air-oxide interface and $\mathrm{NiO}$ between the metal and hydroxide layer. Nickel metallic signal is stronger for graphene-coated $\mathrm{Ni}$ than for bare $\mathrm{Ni}$ samples, regardless heat treatment. However, it is clear that NiT samples, due to oxide removal treatment, are similar to graphene-coated $\mathrm{Ni}$ in terms of metallic Ni composition, indicating that NiT is in fact the control sample for viability, microbial corrosion and sweat exposure measurements.

Contact angle measurements were performed to characterize surface hydrophobicity of coated and uncoated Ni samples (Figure $2 \mathrm{~b}-\mathrm{d}$ ). Hydrophobic force is one of the most important properties involved in the bacterial adhesion process and is determined by physicochemical surface properties [62]. Bacteria are more prone to attach to the hydrophobic surfaces than hydrophilic surfaces [63], and hydrophobicity of the cell surface, such as that reported for E. coli [63], tends to increase adhesion [64]. In the case of nickel, there is a clear transition from hydrophilic surface (contact angle of $\sim 82^{\circ}$ ) for NiT (Figure 2b) to a hydrophobic surface when nickel is covered by few-layer graphene (contact angle of $\sim 96^{\circ}$ for FLG, Figure 2c). An increase in the hydrophobicity has been also reported for graphene grown on $\mathrm{Ni}$ via $\mathrm{SiC}$ sublimation at $1620^{\circ} \mathrm{C}$ [65]. Hydrophobic domains are connected to lower friction force, making the displacement of water molecules in wet environments an easy task for bacteria arriving to 
material's surface that, in the end, favors their adhesion. A similar behavior regarding hydrophobicity is reported for CVD SLG grown on $\mathrm{Cu}$ [41]. According to our measurements surface hydrophobic property of FLG on Ni is not preserved for four layer of graphene transferred on Ni (Figure $2 \mathrm{~d}$ with around $95^{\circ}$ ). These measurements show that bacterial adhesion is expected to be larger for FLG grown on $\mathrm{Ni}$ than for uncoated $\mathrm{Ni}$.

(a)

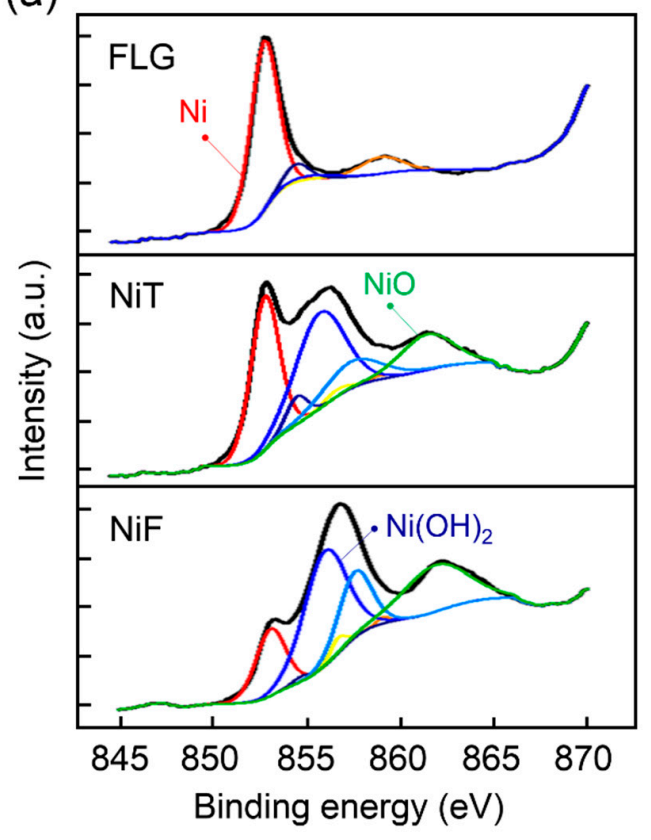

(b)

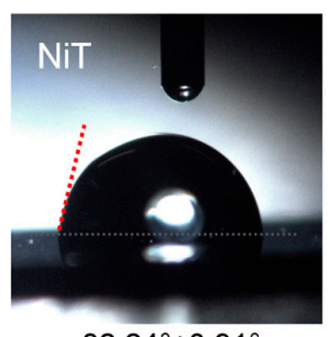

$82.24^{\circ} \pm 0.91^{\circ}$ (c)

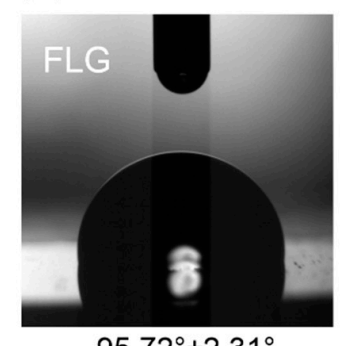

$95.72^{\circ} \pm 2.31^{\circ}$

(d)

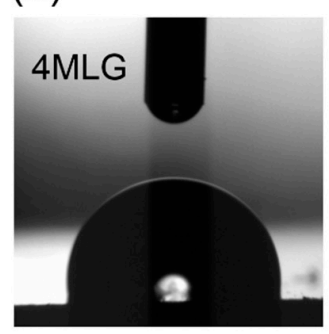

$95.61^{\circ} \pm 1.73^{\circ}$

Figure 2. Surface composition and hidrophobicity of coated and uncoted Ni samples. (a) XPS Ni $2 \mathrm{p}_{3 / 2}$ spectra of coated and uncoated $\mathrm{Ni}$, including peak fitting to identify $\mathrm{Ni}$ (red, yellow and orange), $\mathrm{NiO}$ (green) and $\mathrm{Ni}(\mathrm{OH})_{2}$ (blue) contributions. This allows the identification of FLG control sample (NiT). Images of contact angle measurements using Milli-Q water in contact with (b) NiT; (c) FLG and (d) 4MLG.

In order to detect any interaction between bacteria and $\mathrm{Ni}$ that would lead to microbial corrosion, cell viability was measured. This approach is based in the fact that the main signature of microbial-induced corrosion is ions released from metal surface that, in turn causes, in the case of $\mathrm{Ni}$ ions, cell death $[38,66]$. Bacteria are used, for these purposes, as sensors of nickel ion release. Figure $3 \mathrm{e}$ summarizes cell viability results on $E$. coli after $24 \mathrm{~h}$ of incubation on NiT, NiF and graphene-coated $\mathrm{Ni}$ samples, together with morphology of bacteria after incubation (Figure 3a-d). Cell viability percentage (viability \%) was calculated comparing $\mathrm{CFU}$ at $24 \mathrm{~h}$ and at $\mathrm{t}=0$. For our bacterial interaction measurements NiT was used as control sample of FLG due to the reduced $\mathrm{Ni}(\mathrm{OH})_{2}$ content in that sample compared to NiF (XPS results from Figure 2a).

SEM images of E. coli after $24 \mathrm{~h}$ incubation show that Ni-exposed bacteria (either NiT or NiF) exhibit a wide range of significant abnormalities (Figure $3 \mathrm{~d}, \mathrm{e}$ ), such as a very rough surface or a hollow shape, suggesting that severe damage has occurred leading to the collapse of the cell structure. Such morphological features in bacterial cells are due to disruption of the cell wall due to ions influx, followed by leakage of the cell content [33]. Cell viability results for bacteria incubated on $\mathrm{NiF}$ and $\mathrm{NiT}$ confirmed these results, showing a zero viability value (Figure $3 \mathrm{f}$ ), in agreement with the expected bactericide activity of $\mathrm{Ni}$, connected to highly protein-reactive nature of their ions [66,67]. In contrast, smooth cell surface with regular shape is observed in the case of E. coli on FLG grown on Ni (Figure 3b), similarly to the control sample $\left(\mathrm{SiO}_{2}\right)$ (Figure 3a). This is in agreement with our viability results, which show $100 \%$ and $95 \%$, respectively (Figure 3f). For 4 MLG on Ni a reduction from $10^{8}$ to $2 \times 10^{6} \mathrm{CFU}$ implies a resulting $2 \%$ viability. Transferred FLG and Ni is expected to present weak electronic coupling, 
which suggests that the observed bactericide effect is probably connected to graphene incomplete coverage (intrinsic to PMMA-assisted transfer process) and the consequent release of $\mathrm{Ni}$ ions.

Electron transfer from microbial membranes to graphene has been reported to produce a strong antibacterial effect in graphene grown on copper system [38], where the interaction between copper s electronic states with graphene $\pi$ orbitals is weak [35]. If that were the case such electron-transfer bactericide effect would be amplified for graphene on nickel system, where a stronger chemical interaction results in a hybridization of the $3 \mathrm{~d}$ valence-band states of $\mathrm{Ni}$ with the $\pi$-states of graphene [36]. However, similarity in the results for $\mathrm{FLG}$ and $\mathrm{SiO}_{2}$ (control) samples indicates that a connection between charge transfer from $\mathrm{Ni}$ to bacteria through graphene and their bactericide activity is less likely.

(a)

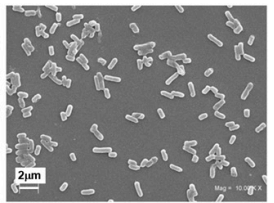

(b)

(c)
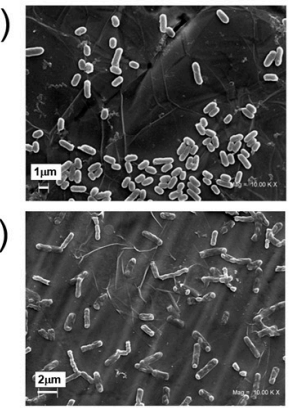

(d)

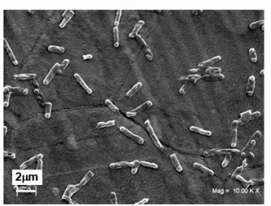

(e)

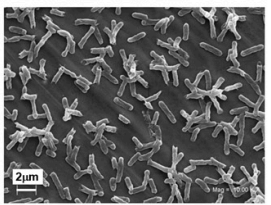

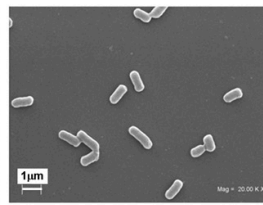
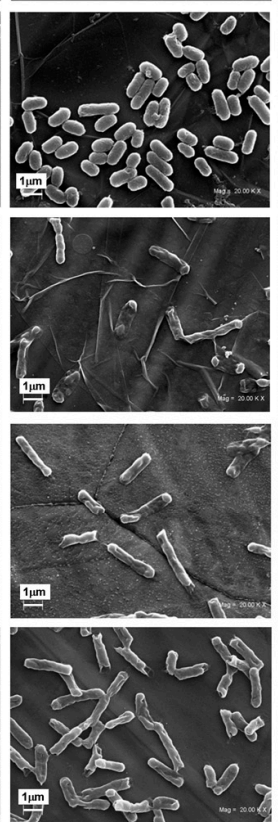
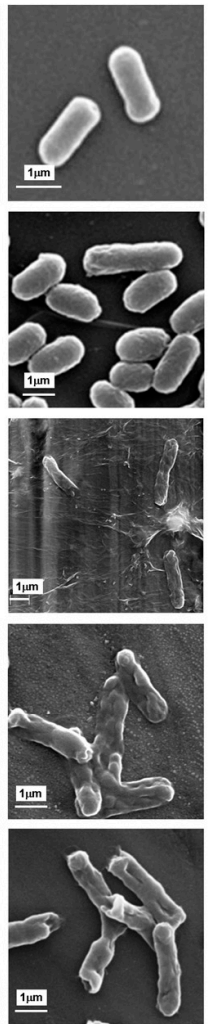

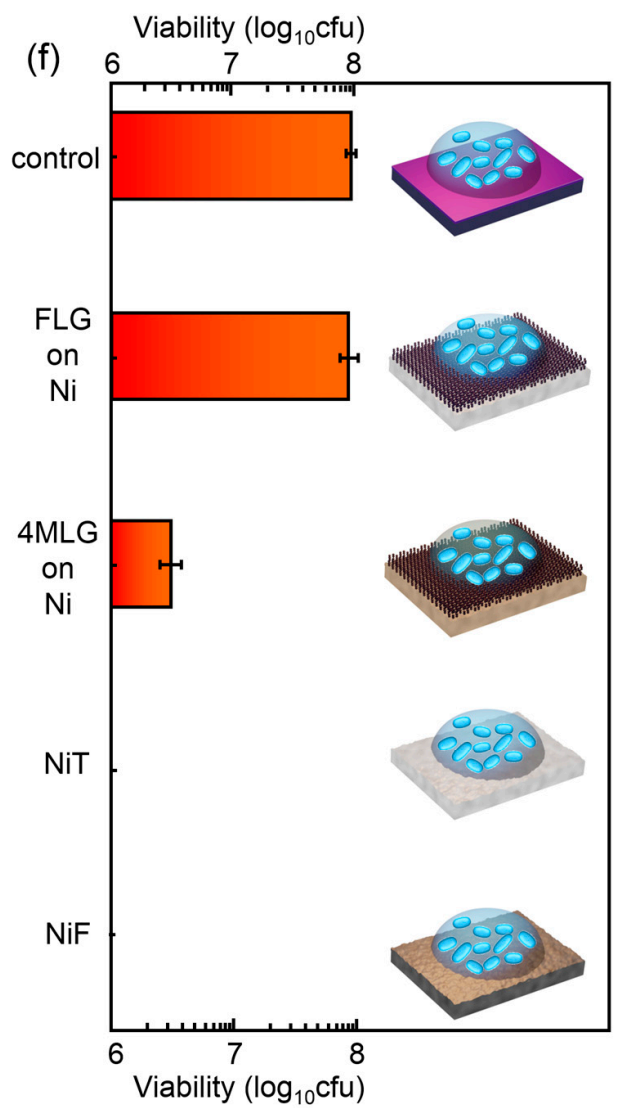

Figure 3. Biological interaction of graphene-coated Ni samples. SEM images of E. coli after $24 \mathrm{~h}$ incubation on: (a) $\mathrm{SiO}_{2}$; (b) FLG grown on $\mathrm{Ni}$; (c) $4 \mathrm{MLG}$ on $\mathrm{Ni}$; (d) NiT and (e) NiF. After incubation on $\mathrm{NiT}$ and $\mathrm{NiF}$ bacteria exhibit damaged membranes, irregular shapes, and rough surfaces, a clear sign of cell lysis. In contrast, intact bacteria were observed when incubated FLG grown on Ni foils. (f) Cell viability of E. coli MG1655 exposed to graphene-coated and uncoated Ni samples (and corresponding control $\mathrm{SiO}_{2}$ ) after $24 \mathrm{~h}$. Fresh and treated $\mathrm{Ni}$ exhibit bactericide activity in contrast to FLG/Ni sample, confirming FLG coating substantially decreases the toxicity of Ni substrate to bacteria, which is connected to a reduced release of $\mathrm{Ni}$ ions.

In parallel, nickel dissolution was studied by ICP to quantify microbial corrosion of graphene-coated and uncoated $\mathrm{Ni}$ samples due to contact with bacterial cultures. Figure 4 shows $\mathrm{Ni}$ ions released from samples exposed to bacteria for $24 \mathrm{~h}$. NiT in contact with Milli-Q water without E. coli cells was chosen as control sample. Solutions with and without bacteria (control) do not contain salts than might affect electrochemical interaction with metal. Dissolved Ni from graphene-coated Ni samples (FLG) in contact with Milli-Q water with bacteria is close to the concentration obtained in control sample. Ni ions release is reduced up to $98.7 \%$ when using FLG 
coating (compare to NiT-control sample of FLG) and up to $46 \%$ when using transferred graphene (compare to $\mathrm{NiF}$-control sample of $4 \mathrm{MLG}$ ). These results demonstrate grown graphitic membranes efficiently protect underlying Ni from microbial corrosion due to bacterial interaction. In particular, Ni dissolution is found to be inversely related to cell viability (Figure 3f), which is in agreement with the proposed mechanism of Ni toxicity, which is thought to be influenced mostly by the influx of nickel ions into the cells. Metal dissolution (resulting from microbial corrosion process for instance) indirectly affects bacteria by incorporating ions into bacterial protein and thereby making the protein non-functional and/or resulting in malfunctioning [66,68]. Coated and uncoated samples were washed with de-ionized water to remove attached biofilm in order to visualize any possible damage at the samples surface. SEM images of NiT and NiF samples after interaction with microorganisms showed localized pit corrosion. Pits presented a non-equiaxed form with size comparable to bacteria dimensions. In contrast, FLG and 4MLG samples exhibited no visible damage, in agreement with ICP measurements.

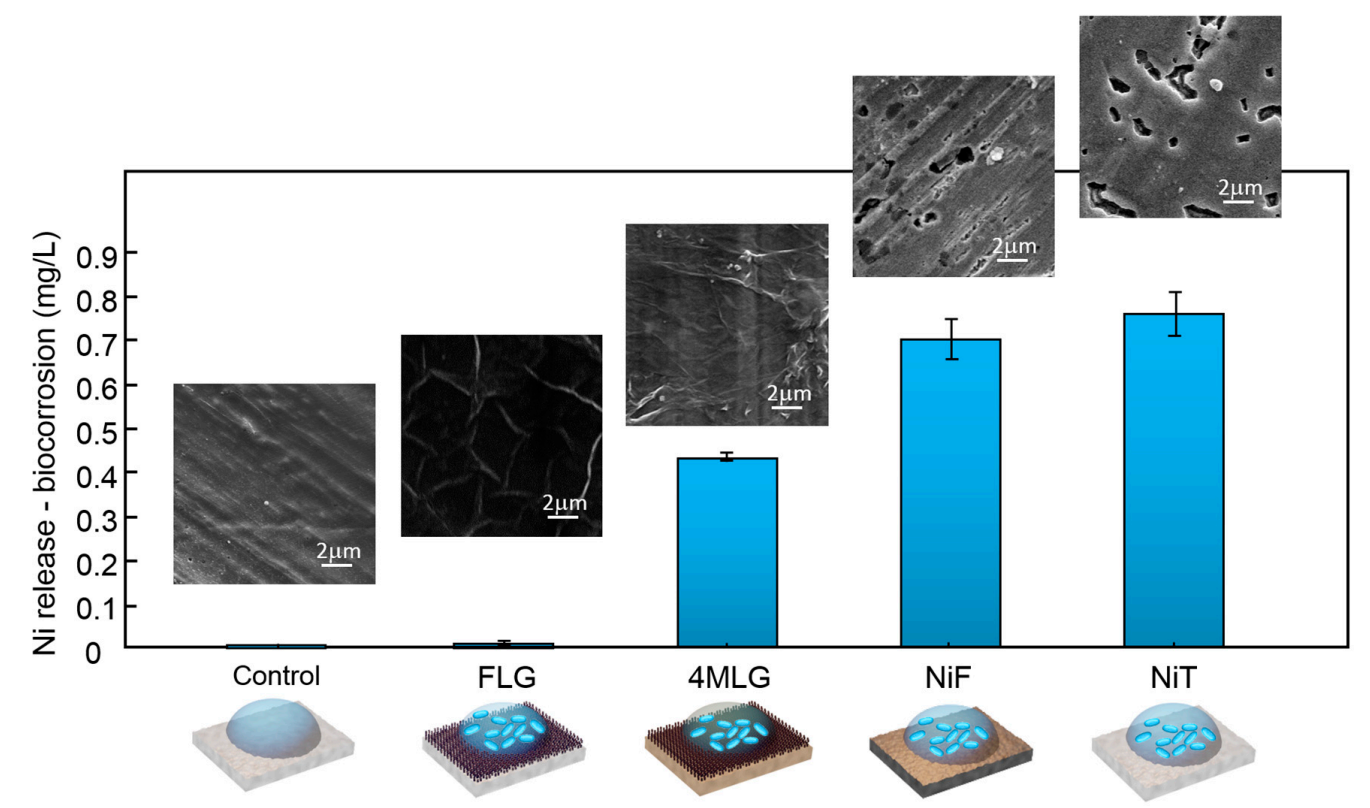

Figure 4. Ni ion release from graphene-coated and uncoated Ni samples. ICP measurements on coated and uncoated Ni samples after $24 \mathrm{~h}$ of bacteria contact showing Ni dissolution. Dissolved $\mathrm{Ni}$ for graphene-coated Ni samples in contact with bacteria (E. coli) is below technique's detection limit, as well as control sample. NiT and NiF in contact with bacteria present high nickel ion release. SEM images show morphology of samples after bacterial exposure.

To study the performance of graphitic coatings under Ni allergy conditions we performed ICP measurements on $\mathrm{Ni}$ dissolution for graphene-coated and uncoated $\mathrm{Ni}$ samples under sweat immersion conditions (source of acute Ni allergic contact hypersensitivity) (Figure 5). Nickel release limit, according the EN1811 standard developed by the European Parliament and Council (Directive 94/27/EC and amended in 2004/96/EC), is $0.5 \mu \mathrm{g} \mathrm{Ni} / \mathrm{cm}^{2}$ per week for articles intended to come into direct and prolonged contact with skin $[21,22]$. Our results show that the release of $\mathrm{Ni}$ ions from uncoated samples (NiT) is 33 times higher than that limit $\left(\sim 16.5 \mu \mathrm{g} / \mathrm{cm}^{2} /\right.$ week) while for graphene-coated samples $\mathrm{Ni}$ ion release reaches a similar value $\left(\sim 0.6 \mu \mathrm{g} / \mathrm{cm}^{2} /\right.$ week).

Different coatings have been reported to be used to reduce Ni release from biomaterials in contact with artificial sweat $[69,70]$. In vivo experiments on human patients with metal allergy, using artificial sweet as eluent, have shown that when stainless steel disks are coated with a biocompatible surface coatings, such as $\mathrm{TiN}$ and $\mathrm{ZrN}$, a reduction of around $70 \%$ in Ni release (compared to uncoated samples) can be reached after 5 days exposure [69]. Similarly, a 55\% Ni release reduction has been found in NiT 
samples coated with a CaP nanometric layer after a week of exposure [70]. Remarkably, our results for 1 week sweat immersion (time defined by international regulation) indicate that FLG coatings are able to reduce up to $96 \%$ the release of $\mathrm{Ni}$ ions, far exceeding previously mentioned coatings. 4MLG coating reduced by $83 \%$ the amount of released $\mathrm{Ni}$ when compare with $\mathrm{NiF}$, which is "control sample" for transferred graphene. The protection performance of transferred coatings under sweat immersion is higher than in the case of microbial corrosion conditions (Figure 4), which might be connected with different metal dissolution rates in both environments.

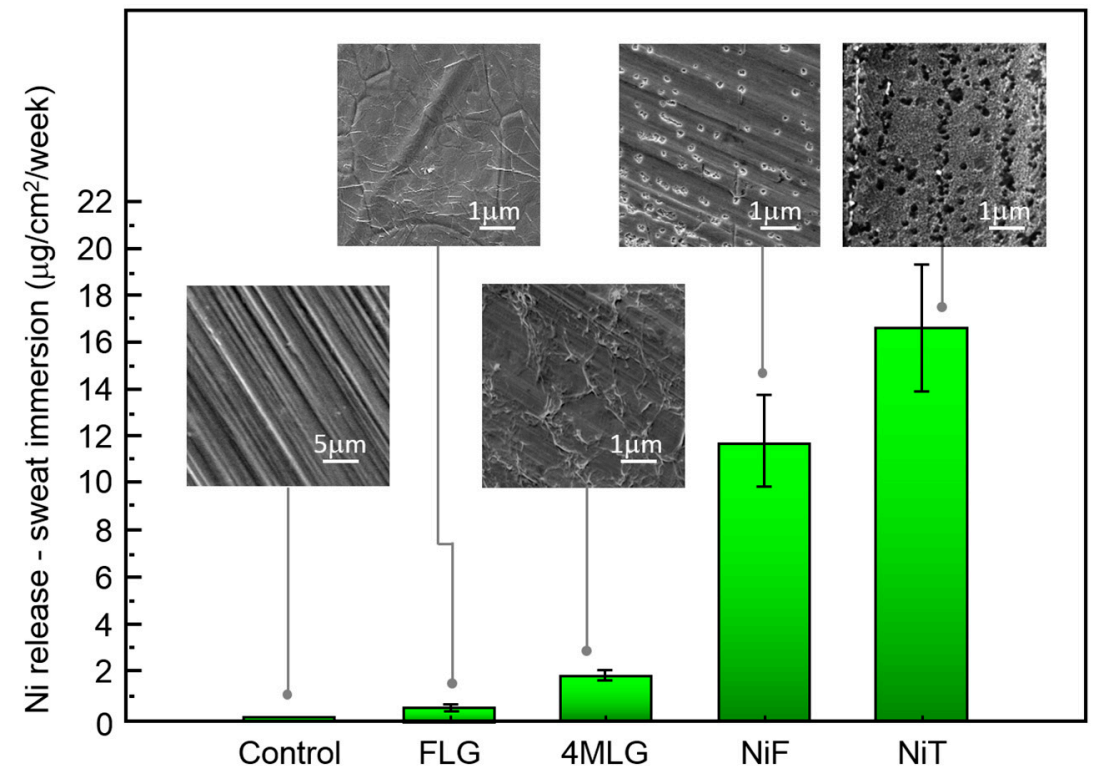

Figure 5. Ni ion release from graphene-coated samples exposed to artificial sweat. ICP measurements on grown and transferred graphene-coated and uncoated Ni samples after 1 week of sweat immersion showing Ni dissolution. Uncoated samples ( $\mathrm{NiT}$ and $\mathrm{NiF}$ ) in contact with sweat present highest $\mathrm{Ni}$ ion release. All samples where $1 \mathrm{~cm}^{2}$. SEM images show morphology of samples after sweat exposure.

SEM micrographs of uncoated Ni samples after sweat exposure (insets in Figure 5) show a pit-like surface damage. Pit size was found to be inferior (and more symmetric in aspect) to the case of bacterial exposure. Coated samples morphology (FLG and 4MLG) is similar to samples before exposure, without any visible damage. SEM and ICP information confirms the ability of FLG coatings (and 4MLG to less extent) to reduce $\mathrm{Ni}$ ion release in $\mathrm{Ni}$ allergy test conditions. Differences between $\mathrm{NiF}$ and $\mathrm{NiT}$ dissolution can be related to composition of surface samples. According to XPS measurements NiF, previous to sweat exposure, displays a higher surface content of nickel hydroxide/oxide and lower content of metallic Ni than NiT. Such oxide porous layers tend to passivate the surface, not allowing a total surface protection but slowing the corrosion process [71]. Such partial protection might be connected to the observed low $\mathrm{Ni}^{2+}$ ion release for $\mathrm{NiF}$, when compare with $\mathrm{NiT}$.

Our results suggest that the observed effectiveness of graphene as a barrier against interaction between $\mathrm{Ni}$ and bacteria or sweat can be understood in terms of graphene permeability. Graphene's p orbitals form a dense and delocalized cloud that blocks the gap within its aromatic rings [72], creating a repelling field, which does not allow molecules (or ions) to pass through. The reported graphene pore size is $64 \mathrm{pm}$ [73], a value smaller than the effective ionic radii of $\mathrm{Ni}^{2+}(70 \mathrm{pm})$ [74], which are responsible for the antibacterial properties of $\mathrm{Ni}$. In the case of FLG grown on $\mathrm{Ni}$, the superposition of such impermeable effect for around 4 layers makes this barrier even more effective. Damage at graphene layer when transferred onto $\mathrm{Ni}$ (intrinsic to PMMA-assisted transfer process) leads to a lower efficiency barrier than in the case of grown graphene.

Figure 6 summarizes the interaction between coated and uncoated Ni samples with bacteria and sweat. Figure 6a shows that a strong interaction between bacteria and uncoated Ni samples determines 
dissolution of $\mathrm{Ni}$ (biocorrosion), which ions penetrate microbial cells, inactivating their enzymes and causing death of microorganisms. When uncoated samples are exposed to sweat for a week (Figure $6 \mathrm{c}$ ), a strong dissolution is observed, leading to a pit pattern on Ni surface. When the metallic substrates are covered by a graphitic membrane (grown or transferred) we observed a considerable reduction in $\mathrm{Ni}$ dissolution due to bacteria (biocorrosion) and sweat contact (Figure $6 \mathrm{~b}, \mathrm{~d}$ respectively). The absence of electron-transfer bactericide effect in this highly hybridized system suggests this protection effect is presumably connected to impermeability of graphene membranes to Ni ions transfer (Figure 6e), similarly to the case of SLG on $\mathrm{Cu}$, that suppress $\mathrm{Cu}^{2+}$ ions release from $\mathrm{Cu}$ foils in contact with bacteria [41]. The proposed protection mechanism is proven to be efficient even under more critical conditions, such as an increased bacterial adhesion to hydrophobic graphene/Ni surface.

(a)

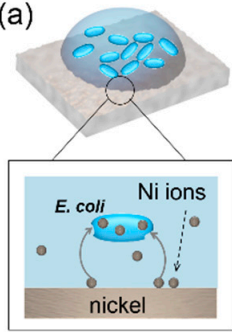

(b)

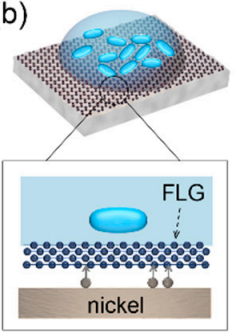

(c)

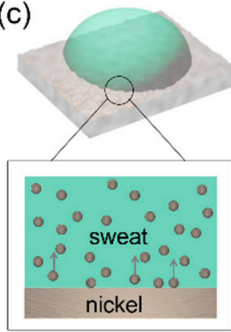

(d)

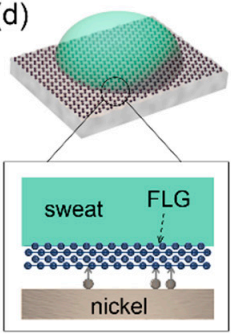

(e)

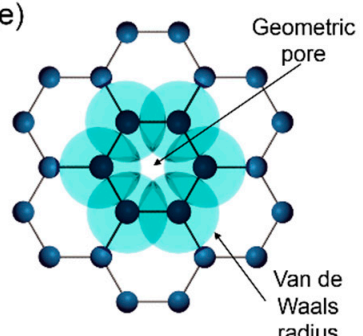

Figure 6. Diagram of FLG-coated Ni performance under biocorrosion and Ni hypersensitivity conditions inferred from our study. (a) Uncoated Ni samples (NiT or NiF) interacts with bacteria, releasing metal ions which lead to cell death; (b) For graphene-coated Ni, there is no interaction between bacteria and underlying substrate, leading to reduction of biocorrosion and, in consequence decrease of Ni bactericide activity; (c) Sweat, in contact with Ni (fresh or treated), boosts release of a high amount of $\mathrm{Ni}$ ions; (d) Graphene coating prevent $\mathrm{Ni}$ ions release in sweat which is related to $\mathrm{Ni}$ hypersensitivy in humans; (e) Geometric pore size of graphene determines a high impermeability to $\mathrm{Ni}$ ions.

\section{Conclusions}

In conclusion, we studied the performance of graphitic coatings as a protection barrier under microbial corrosion and $\mathrm{Ni}$ allergy conditions. From the microbial corrosion point of view, cell viability and $\mathrm{Ni}$ dissolution results indicate these nanostructured coatings effectively block interaction between bacteria and underlying metal. The absence of bactericide effect for this highly electronically hybridized system suggests that most of the protection from the observed protection from biological environment can be understood in terms of graphene impermeability to transfer $\mathrm{Ni}^{2+}$ ions, which is enhanced for a few layers of graphene.

This protective effect of impermeable graphene coatings is extended to the case of $\mathrm{Ni}$ allergy conditions. Although Ni dissolution does not remain below the value established by international Directive 94/27/EC in graphene-coated Ni samples, its proximity to this value confirms the great potential of graphitic coatings to prevent the significant amounts of nickel ions usually released from metallic devices, which may interact with the human body causing adverse health effects. The most effective way of preventing nickel allergy is the avoidance of exposure. The ideal case would be the complete ban of nickel use, which is irrelevant due the wide distribution of the metal worldwide. In this scenario the observed performance of graphitic coatings to prevent $\mathrm{Ni}$ ion release suggests a promising new venue to prevent allergy reactions. Further in vivo experiments are needed to evaluate biocompatibility of graphene-coated materials on humans and animals.

Acknowledgments: This work was financially supported by FONDEF ID15I10576, Proyecto Interno DGIP 216.11.1, Fondecyt 1160811, Fondecyt de iniciación 11140787 and INCT Nanocarbono.

Author Contributions: Carolina Parra, Francisco Montero-Silva design the experiment. Carolina Parra, Dana Gentil, Valeria del Campo, Thiago Henrique Rodrigues da Cunha, Ricardo Henríquez, Patricio Häberle, 
Carolina Garín, Cristian Ramírez, Marcos Flores, Michael Seeger carried out the synthesis and characterization of nanomaterials. Francisco Montero-Silva carried out microbiological experiment. Carolina Parra and Francisco Montero-Silva analyzed the data and wrote the manuscript. Thiago Henrique Rodrigues da Cunha, Valeria del Campo, Raúl Fuentes and Ricardo Henríquez participated in the data analysis and manuscript preparation. All authors discussed, read, and approved the final manuscript.

Conflicts of Interest: The authors declare no conflict of interest.

\section{References}

1. Rao, T. Microbial fouling and corrosion: Fundamentals and mechanisms. In Operational and Environmental Consequences of Large Industrial Cooling Water Systems; Springer: Boston, MA, USA, 2012; pp. 95-126.

2. Li, K.; Whitfield, M.; van Vliet, K.J. Beating the bugs: Roles of microbial biofilms in corrosion. Corros. Rev. 2013, 31, 73-84.

3. Almeida, C.; Azevedo, N.; Santos, S.; Keevil, W.; Vieira, M. Discriminating multi-species populations in biofilms with peptide nucleic acid fluorescence in situ hybridization (PNA FISH). PLoS ONE 2011, 6, e14786. [CrossRef] [PubMed]

4. Videla, H.; Herrera, L. Understanding microbial inhibition of corrosion. A comprehensive overview. Int. Biodeterior. Biodegrad. 2009, 63, 896-900. [CrossRef]

5. Zhang, W.; Lee, S.; McNear, K.L.; Chung, T.F.; Lee, S.; Lee, K.; Crist, S.; Ratliff, T.L.; Zhong, Z.; Chen, Y.P.; et al. Use of graphene as protection film in biological environments. Sci. Rep. 2014, 4, 4097-4105. [CrossRef] [PubMed]

6. Scott-Fordsmand, J. Toxicity of nickel to soil organisms in Denmark. Rev. Environ. Contam. Toxicol. 1997, 148, $1-34$.

7. Poonkothai, M.; Shyamala, B. Nickel as an essential element and a toxicant. Int. J. Environ. Sci. 2012, 1, 285-288.

8. Thyssen, J.; Johansen, J.; Menne, T.; Nielsen, N.; Linneberg, A. Nickel allergy in Danish women before and after nickel regulation. N. Engl. J. Med. 2009, 360, 2259-2260. [CrossRef] [PubMed]

9. Thyssen, J.; Ross-Hansen, K.; Menne, T.; Johansen, J. Patch test reactivity to metal allergens following regulatory interventions: A 33-year retrospective study. Contact Dermat. 2010, 63, 102-106. [CrossRef] [PubMed]

10. Jacob, S.; Moennich, J.; McKean, B.; Zirwas, M.; Taylor, J. Nickel allergy in the United States: A public health issue in need of a 'nickel directive'. J. Am. Acad. Dermatol. 2009, 60, 1067-1069. [CrossRef] [PubMed]

11. Nosbaum, A.; Nosbaum, L.; Rival-Tringali, A.; Barth, X.; Damon, H.; Vital-Durand, D.; Claudy, A.; Faure, M. Nickel-induced systemic allergic dermatitis from a sacral neurostimulator. Contact Dermat. 2008, 59, 319-320. [CrossRef] [PubMed]

12. Lidén, C.; Carter, S. Nickel release from coins. Contact Dermat. 2001, 44, 160-165. [CrossRef]

13. Spiewak, R.; Pietowska, J.; Curzytek, K. Nickel: A unique allergen-From molecular structure to European legislation. Expert Rev. Clin. Immunol. 2007, 3, 851-859. [CrossRef] [PubMed]

14. Roediger, B.; Weninger, W. How nickel turns on innate immune cells. Immunol. Cell Biol. 2011, 89, 1-2. [CrossRef] [PubMed]

15. Thyssen, J.; Gawkrodger, J.; White, I.; Lidén, C. Coin exposure may cause allergic nickel dermatitis: A review. Contact Dermat. 2013, 68, 3-14. [CrossRef] [PubMed]

16. Thyssen, J.; Menne, T.; Johansen, J. Identification of metallic items that caused nickel dermatitis in Danish patients. Contact Dermat. 2010, 63, 151-156. [CrossRef] [PubMed]

17. Suneja, T.; Flanagan, K.; Glaser, D. Blue-jean button nickel: Prevalence and prevention of its release from buttons. Dermatitis 2007, 18, 208-211. [CrossRef] [PubMed]

18. Svedman, C.; Ekqvist, S.; Möller, H.; Björk, J.; Pripp, C.; Gruvberger, B.; Holmström, E.; Gustavsson, C.; Bruze, M.A. Correlation found between contact allergy to stent material and restenosis of the coronary arteries. Contact Dermat. 2009, 60, 158-164. [CrossRef] [PubMed]

19. Schmidt, M.; Goebeler, M. Nickel allergies: Paying the toll for innate immunity. J. Mol. Med. 2011, 89, 961-970. [CrossRef] [PubMed]

20. Wilkinson, D.; Wilkinson, J. Nickel allergy and hand eczema. In Nickel and the Skin: Immunology Toxicology; Maibach, H.I., Menne, T., Eds.; CRC Press: Boca Raton, FL, USA, 1989; pp. 133-164. 
21. European Parliament and Council Directive 94/27/EC. Official Journal of the European Communities. 1994. Available online: https:/ / publications.europa.eu/en/publication-detail/-/publication/0a5a20d2063e-4892-b94d-d82c9b223de0/language-en (accessed on 27 October 2017).

22. European Parliament and Council Directive 1907/2006/EC. Official Journal of the European Communities. 2017. Available online: http:/ / eur-lex.europa.eu/legal-content/EN/TXT/PDF/?uri=uriserv:OJ.C_.2017. 011.01.0013.01.ENG (accessed on 27 October 2017).

23. Memon, A.; Molokhia, M.; Friedmann, P. The inhibitory effects of topical chelating agents and antioxidants on nickel-induced hypersensitivity reactions. J. Am. Acad. Dermatol. 1994, 30, 560-565. [CrossRef]

24. Wöhrl, S.; Kriechbaumer, N.; Hemmer, W.; Focke, M.; Brannath, W.; Götz, M.; Jarisch, R.A. Cream containing the chelator DTPA (diethylenetriaminepentaacetic acid) can prevent contact allergic reactions to metals. Contact Dermat. 2001, 44, 224-228. [CrossRef]

25. Christensen, O.; Kristensen, M. Treatment with disulfiram in chronic nickel hand dermatitis. Contact Dermat. 1982, 8, 59-63. [CrossRef]

26. Hopfer, S.; Linden, J.; Rezuke, W.; O’Brien, J.; Smith, L.; Watters, F.; Sunderman, F. Increased nickel concentrations in body fluids of patients with chronic alcoholism during disulfiram therapy. Res. Commun. Chem. Pathol. Pharmacol. 1987, 55, 101-109. [PubMed]

27. Wall, L. Nickel penetration through rubber gloves. Contact Dermat. 1980, 6, 461-463. [CrossRef]

28. Vemula, P.; Anderson, R.; Karp, J. Nanoparticles reduce nickel allergy by capturing metal ions. Nat. Nanotechnol. 2011, 6, 291-295. [CrossRef] [PubMed]

29. Alarifi, S.; Ali, D.; Verma, A.; Alakhtani, S.; Ali, B.A. Cytotoxicity and genotoxicity of copper oxide nanoparticles in human skin keratinocytes cells. Int. J. Toxicol. 2013, 32, 296-307. [CrossRef] [PubMed]

30. Sajid, M.; Ilyas, M.; Basheer, C.; Tariq, M.; Daud, M.; Baig, N.; Shehzad, F. Impact of nanoparticles on human and environment: Review of toxicity factors, exposures, control strategies, and future prospects. Environ. Sci. Pollut. Res. 2015, 22, 4122-4143. [CrossRef] [PubMed]

31. Le, Y.; Hou, P.; Wang, J.; Chen, J.F. Controlled release active antimicrobial corrosion coatings with $\mathrm{Ag} / \mathrm{SiO} 2$ core-shell nanoparticles. Mater. Chem. Phys. 2010, 120, 351-355. [CrossRef]

32. Kwaadsteniet, M.; Botes, M.; Cloete, T.E. Application of nanotechnology in antimicrobial coatings in the water industry. Nano 2011, 6, 395-407. [CrossRef]

33. Parra, C.; Montero-Silva, F.; Henriquez, R.; Flores, M.; Garín, C.; Ramírez, C.; Moreno, M.; Correa, J.; Seeger, M.; Häberle, P. Suppressing bacterial interaction with copper surfaces through graphene and hexagonal-boron nitride coatings. ACS App. Mater. Interfaces 2015, 7, 6430-6437. [CrossRef] [PubMed]

34. Krishnamurthy, A.V.; Gadhamshetty, R.; Mukherjee, Z.; Chen, W.; Ren, H.; Cheng, M.; Koratkar, N. Passivation of microbial corrosion using a graphene coating. Carbon 2013, 56, 45-49. [CrossRef]

35. Liu, H.; Kondo, H.; Ohno, T. Spintronic transport in armchair graphene nanoribbon with ferromagnetic electrodes: Half-metallic properties. Nanoscale Res. Lett. 2016, 11, 456. [CrossRef] [PubMed]

36. Dedkov, Y.; Fonin, M. Electronic and magnetic properties of the grapheme-ferromagnet interface. New J. Phys. 2010, 12, 125004. [CrossRef]

37. Gong, C.; Lee, G.; Shan, B.; Vogel, E.M.; Wallace, R.M.; Cho, K. First-principles study of metal-graphene interfaces. J. Appl. Phys. 2010, 108, 123711. [CrossRef]

38. Li, J.; Wang, G.; Zhu, H.; Zhang, M.; Zheng, X.; Di, Z.; Liu, X.; Wang, X. Antibacterial activity of large-area monolayer graphene film manipulated by charge transfer. Sci. Rep. 2014, 4, 4359-4366. [CrossRef] [PubMed]

39. Raman, R.S.; Tiwari, A. Graphene: The thinnest known coating for corrosion protection. JOM 2014, 66, 637-642. [CrossRef]

40. Hsieh, Y.P.; Hofmann, M.; Chang, K.W.; Jhu, J.G.; Li, Y.Y.; Chen, K.Y.; Yang, C.C.; Chang, W.S.; Chen, L.C. Complete corrosion inhibition through graphene defect passivation. ACS Nano 2013, 8, 443-448. [CrossRef] [PubMed]

41. Parra, C.; Dorta, F.; Jiménez, E.; Henríquez, R.; Ramírez, C.; Rojas, R.; Villalobos, P. Nanomolecular approach to reveal decreased adhesion of biofouling-producing bacteria to grapheme-coated material. J. Nanobiotechnol. 2015, 13, 82-91. [CrossRef] [PubMed]

42. Al-Thani, R.F.; Patan, N.K.; Al-Maadeed, M.A. Graphene oxide as antimicrobial against two gram-positive and two gram-negative bacteria in addition to one fungus. OnLine J. Biol. Sci. 2014, 14, 230-239. [CrossRef]

43. Wang, X.; Li, J.; Zhong, Q.; Zhong, Y.; Zhao, M.K. Controlled synthesis of surface-clean monolayer graphene. Key Eng. Mater. 2013, 562, 85-90. [CrossRef] 
44. Tian, J.; Hu, B.; Wei, Z.; Jin, Y.; Luo, Z.; Xia, M.; Pan, Q.; Liu, Y. Surface structure deduced differences of copper foil and film for graphene CVD growth. App. Surf. Sci. 2014, 300, 73-79. [CrossRef]

45. Juang, Z.Y.; Wu, C.Y.; Lu, A.Y.; Su, C.Y.; Leou, K.C.; Chen, F.R.; Tsai, C.H. Graphene synthesis by chemical vapor deposition and transfer by a roll-to-roll process. Carbon 2010, 48, 3169-3174. [CrossRef]

46. Barin, G.B.; Song, Y.; de Fátima Gimenez, I.; Souza Filho, A.G.; Barreto, L.S.; Kong, J. Optimized graphene transfer: Influence of polymethylmethacrylate (PMMA) layer concentration and baking time on graphene final performance. Carbon 2015, 84, 82-90. [CrossRef]

47. Jin, W.; Hao, Q.; Peng, X.; Chu, P.K. Enhanced corrosion resistance and biocompatibilty of PMMA-coated ZK60 magnesium alloy. Mater. Lett. 2016, 173, 178-181. [CrossRef]

48. De Jesús, J.; Carrazza, J.; Pereira, P.; Zaera, F. Hydroxylation of NiO films: The effect of water and ion bombardment during the oxidation of $\mathrm{Ni}$ foils with $\mathrm{O}_{2}$ under vacuum. Surf. Sci. 1998, 397, 34-47. [CrossRef]

49. Bruinsma, G.; van der Mei, H.; Busscher, H. Bacterial adhesion to surface hydrophilic and hydrophobic contact lenses. Biomaterials 2001, 22, 3217-3224. [CrossRef]

50. Ramírez, C.; Gallegos, I.; Ihl, M.; Bifani, V. Study of contact angle, wettability and water vapor permeability in carboxymethylcellulose (CMC) based film with Murta leaves (Ugni molinae Turcz) extract. J. Food Eng. 2012, 109, 424-429. [CrossRef]

51. Nan, L.; Xu, D.; Gu, T.; Song, X.; Yang, K. Microbiological influenced corrosion resistance characteristics of a 304L-Cu stainless steel against Escherichia coli. Mat. Sci. Eng. C Mater. Biol. Appl. 2015, 48, 228-234. [CrossRef] [PubMed]

52. Javed, M.A.; Stoddart, P.R.; Palombo, E.A.; McArthur, S.L.; Wade, S.A. Inhibition or acceleration: Bacterial test media can determine the course of microbiologically influenced corrosion. Corros. Sci. 2014, 86, 149-158. [CrossRef]

53. Chirino, B.; Strahsburger, E.; Agulló, L.; González, M.; Seeger, M. Genomic and functional analyses of the 2-aminophenol catabolic pathway and partial conversion of its substrate into picolinic acid in Burkholderia xenovorans LB400. PLoS ONE 2013, 8, e75746. [CrossRef] [PubMed]

54. Luvara, G. Reference Test Method for Release of Nickel from Products Intended to Come into Direct and Prolonged Contact with the Skin; British Standards Institution: London, UK, 1999.

55. Brugnoni, C.; Bianchi, R.; Binchini, A.; Stroosnijder, M. Influence of experimental test conditions on the Ni release of a Cu-Ni alloy in artificial sweat. In Materials for Medical Engineering; Wiley-VCH Verlag GmbH \& Co. KGaA: Weinheim, Germany, 2000.

56. Zhang, Y.; Gao, T.; Xie, S.; Dai, B.; Fu, L.; Gao, Y.; Chen, Y.; Liu, M.; Liu, Z. Different growth behaviors of ambient pressure chemical vapor deposition graphene on $\mathrm{Ni}(111)$ and $\mathrm{Ni}$ films: A scanning tunneling microscopy study. Nano Res. 2012, 5, 402-411. [CrossRef]

57. Cao, H.; Yu, Q.; Colby, R.; Pandey, D.; Park, C.; Lian, J.; Zemlyanov, D.; Childres, I.; Drachev, V.; Stach, E.; et al. Large-scale graphitic thin films synthesized on $\mathrm{Ni}$ and transferred to insulators: Structural and electronic properties. J. Appl. Phys. 2010, 107, 044310. [CrossRef]

58. Hao, Y.; Wang, Y.; Wang, L.; Ni, Z.; Wang, Z.; Wang, R.; Koo, C.K.; Shen, Z.; Thong, J.T. Probing layer number and stacking order of few-layer graphene by Raman spectroscopy. Small 2010, 6, 195-200. [CrossRef] [PubMed]

59. Reina, A.; Jia, X.; Ho, J.; Nezich, D.; Son, H.; Bulovic, V.; Dresselhaus, M.; Kong, J. Large area, few-layer graphene films on arbitrary substrates by chemical vapor deposition. Nano Lett. 2008, 9, 30-35. [CrossRef] [PubMed]

60. Lambers, E.; Dykstal, C.; Seo, J.; Rowe, J.; Holloway, P. Room-temperature oxidation of Ni(110) at low and atmospheric oxygen pressures. Oxid. Met. 1996, 45, 301-321. [CrossRef]

61. Lv, J.; Wang, Z.; Liang, T.; Meng, Y.; Suzuki, K.; Miura, H. The effect of graphene coated nickel foam on the microstructures of $\mathrm{NiO}$ and their supercapacitor performance. J. Electroanal. Chem. 2017, 799, 595-601.

62. Stalder, A.; Kulik, G.; Sage, D.; Barbieri, L.; Hoffmann, P. A Snake-based approach to accurate determination of both contact points and contact angles. Colloids Surf. A Physicochem. Eng. Asp. 2006, 286, 92-103. [CrossRef]

63. Busscher, H.; Weerkamp, A.H. Specific and non-specific interactions in bacteria adhesion to solid substrata. FEMS Microbiol. Lett. 1987, 46, 165-173. [CrossRef]

64. Méndez-Vilas, A. Microbial Pathogens and Strategies for Combating Them: Science, Technology and Education; Research Center: Badajoz, Spain, 2013; pp. 1230-1246. 
65. Munz, M.; Giusca, C.E.; Myers-Ward, R.L.; Gaskill, D.K.; Kazakova, O. Thickness-dependent hydrophobicity of epitaxial graphene. ACS Nano 2015, 9, 8401-8411. [CrossRef] [PubMed]

66. Donlan, R. Biofilms: Microbial life on surfaces. Emerg. Infect. Dis. 2002, 8, 881-890. [CrossRef] [PubMed]

67. Popova, T.; Alexandrova, R.; Tudose, R.; Mosoarca, M.; Costisor, O. Antimicrobial activity in vitro of four nickel complexes. Bulg. J. Agric. Sci. 2012, 18, 446-450.

68. Fage, S.; Faurschou, A.; Thyssen, J. Copper hypersensitivity. Contact Dermat. 2014, 71, 191-201. [CrossRef] [PubMed]

69. Yasuyuki, M.; Kunihiro, K.; Kurissery, S.; Kanavillil, N.; Sato, Y.; Kikuchi, Y. Antibacterial properties of nine pure metals: A laboratory study using Staphylococcus aureus and Escherichia coli. Biofouling 2010, 26, 851-858. [CrossRef] [PubMed]

70. Thomas, P.; Weik, T.; Roider, G.; Summer, B.; Thomsen, M. Influence of surface coating on metal ion release: Evaluation in patients with metal allergy. Orthopedics 2016, 39, S24-S30. [CrossRef] [PubMed]

71. Surmenev, R.A.; Ryabtseva, M.A.; Shesterikov, E.V.; Pichugin, V.F.; Peitsch, T.; Epple, M. The Release of nickel from nickel-titanium (NiTi) is strongly reduced by a sub-micrometer thin layer of calcium phosphate deposited by rf-magnetron sputtering. J. Mater. Sci. Mater. Med. 2010, 21, 1233-1239. [CrossRef] [PubMed]

72. Elhadiri, H.; Chegdani, K.; Sobh, M.; Cherkaoui, M.; Rifi, E.H. Study of the behavior of Moroccan coin $\frac{1}{2} \mathrm{DH}$ in a simulated sweat solution and 3\% NaCl. J. Mater. Environ. Sci. 2014, 5, 1557-1564.

73. Sreeprasad, T.; Berry, V. How do the electrical properties of graphene change with its functionalization? Small 2013, 9, 341-350. [CrossRef] [PubMed]

74. Berry, V. Impermeability of graphene and its applications. Carbon 2013, 62, 1-10. [CrossRef]

(C) 2017 by the authors. Licensee MDPI, Basel, Switzerland. This article is an open access article distributed under the terms and conditions of the Creative Commons Attribution (CC BY) license (http://creativecommons.org/licenses/by/4.0/). 